\title{
Battling Mainstream Media, Commentators and Organized Debaters Experiences from Citizens' Online Opinion Writing in Sweden
}

\author{
Sofia Larsson
}

\begin{abstract}
This article presents the results of a qualitative interview study on citizen opinion writers who are active on a citizen media website in Sweden. The study explores the writers' experiences of participating in the alternative and citizen media landscape online, their purposes, the benefits and finally what impedes their participation. The results paint a picture of a sole grass-roots writer who aims to reach the broad political sphere using a mix of strategies to participate, oppose the mainstream media or use the Web as a writing gym. The restrictive powers they encounter are associated with mainstream media, commentators and organized debaters. This is discussed as causing a narrower public debate, less participation and less counter-hegemonic content.
\end{abstract}

Keywords: citizen journalism, alternative media, opinion, Internet, counter-hegemony, media participation

\section{Introduction}

The Internet has been said to create a "new public space for political discussion" and to serve as an important tool for "political underdogs" (Papacharissi 2002: 23). Through web-based media, the audience can become "journalists" and thus more voices will be heard (Gillmor 2006). The potential of the Internet to revitalize public debate is a vision that has inspired a multitude of studies, but what do we know about the "underdogs"" experiences in their struggle to be heard? In their review of online journalism research, Michelstein and Boczkowski (2009) emphasize that there is a shortage of ethnographic studies of user-authored content and a need for studies of the practices and experiences of bloggers and citizen journalists. In the present article, the stories of the non-professional sole grass-roots writers are in focus - those who fill the Web's alternative spaces with opinions and discussions. How do they experience using the Web for participating in public debates? What are their aims and how do they describe the new media landscape? The article contributes to the field by qualitatively analysing these writers' practices and objectives and revealing the restrictive powers of online debates.

The approach is to view the new and alternative media online as a political field in which a struggle over meaning-making is continuously taking place, a perspective 
inspired by discourse theory (Laclau \& Mouffe 2001). Their practices, ideas and experiences are also analysed from a power perspective and using the concepts of participation and hegemony. This approach enables a discussion of the grass-roots writers' conditions to participate in and impact debates on the Web.

Citizen opinion writers and debaters can be found in various media online: blogs, citizen journalism webs, social media and forums, to mention a few. Citizens' writing online has interested researchers from various perspectives, such as its addition of diversity (Carpenter 2010) and enablement of participation in the public debate (Dahlgren 2005, Papacharissi 2002), and has also been discussed as a form of resistance through the production of alternative media (Bailey, Cammaerts \& Carpentier 2008, Downey and Fenton 2003, Fenton 2008). Their possibility to revitalize the public debate has also been discussed, for example that forums for political discussions are used only by few (Winsvold 2009, Wojcieszak \& Mutz 2009) or that there may be distinct inequality among participants (Himelboim 2011). Furthermore, blogs are said to cover the same topics as mainstream news or to just extend the mainstream (Dahlgren 2011, Lee 2007).

\section{Theoretical Framework}

The theoretical framework of discourse theory (Laclau \& Mouffe 2001) and agonistic democracy (Mouffe 2005) contain some key concepts that are useful in the present study.

The concept of the political is described as the sphere characterized by "power, conflict and antagonism" (Mouffe 2005: 9). This dimension of society can take different forms and exist in diverse social relations. It is not the same as politics, which refers to the practices and institutions of a society that are aimed at organizing it and establishing order. The present study views the online alternative media landscape as part of the political where conflicts and powers are in motion. For Mouffe, the antagonistic character is inherent in human society, and one important part of her theory of agonism is that we have to acknowledge this dimension, and that to be able to create a we there must be a them.

Hegemony is the other key concept used. Mouffe (2005: 16) states that every societal order is hegemonic in its nature. Furthermore, every society is an outcome of the practices that created the order, nevertheless the order can be opposed by counter-hegemonic practices "which will attempt to disarticulate the existing order so as to install other forms of hegemony" (2005: 18). Articulations such as texts and debates can reproduce or challenge discourses by the way they fix meaning (Winther Jørgensen and Phillips 2002: 29). In the present study, hegemony and counter-hegemony are concepts that enable a power perspective on the grass-roots writers' ideas and practices.

Within the agonistic model of democracy, there is criticism of the consensus- and rationality-based deliberative democratic model that Mouffe regards as leading to a narrowing of the political field. Our era's talk of consensus is thought to lead to less interest in politics. Political mobilization requires the affective dimension, identification, and that one can identify with a camp that is distinct from other alternatives. The passion and the we/them distinction are regarded as vital to political participation (2005: 25). 


\section{Participation}

Carpentier and Dahlgren (2011) discuss the concept of participation within the framework of communication and media studies. Participation is interpreted differently by different democratic theories, which have diverse ideas about what should be considered participation and how much a citizen should participate. This study adopts a maximalist view of participation, placing more emphasis on participation than representation, and it also adopts a broad definition of the political sphere (Carpentier 2011a: 17). Carpentier (2011b: 24) stresses that the political-democratic is not restricted to the institutions of politics, but instead that the political "permeates every possible societal field", a view that the present study adopts.

One key characteristic of participation is power, and Carpentier (2011b) grounds the definition in democratic theory to show that power is important in defining the concept. For example, true participation can be partial (having influence) or full (having decisionmaking power) (Pateman 1970), anything less is pseudo-participation. Accordingly, to avoid over-stretching the concept, the definition of media participation emphasizes the difference between access, interaction and participation, the first two of which are less related to power (meaning influence or decision-making). Carpentier adopts Michel Foucault's idea that power is not in the hands of any societal group, but is instead an "always-present characteristic of social relations" (Carpentier 2011b: 24). Furthermore, Carpentier (2011a: 141) discusses the productivity of power as having three aspects generative, restrictive and resistance - which shows the complexity of power. In the media-sphere, these aspects can be seen as generative in regard to citizens' opportunity to participate, as restrictive when no access is given for the non-elite or as resisting power by turning to alternative media (Carpentier 2011a:147).

One key distinction to further understand participation that Carpentier (2007: 88) discusses is the one between participation in and through the media. The first can be content- or decision-related, a micro-participation that enables the development of civic attitudes. The second refers to "mediated participation in the public debate and for selfrepresentation in the variety of public spaces that characterize the social" (Carpentier 2011a: 67), thus macro-participation. Participation in media production can, according to this model, lead to participation in society.

\section{Alternative and Citizen Media}

Atton (2002: 159) asks if it makes any sense to talk of alternative media in cyberspace, as web media offer a horizontal networked information flow whereby everyone can become his or her own producer, hence the characteristics of alternative media are inherent in the media format. Alternative media theory, defined by Atton (2002: 7), is described as both alternative and radical, but not limited to political and resistance media. He also includes hybrid electronic media and fanzines. Alternative media is also defined as media produced by the socially, culturally and politically excluded (Coyer et al. 2007: 3).

The diversity of alternative media is captured by Bailey et al. (2008) in their four approaches to alternative media: "Serving the community", "An alternative to mainstream media", "Linking alternative to the civil society" and "Alternative media as rhizome". Fuchs (2010) defines alternative media as critical media (in contrast to mainstream media, which are ideological) where the contents produced by grass-roots citizen journalists 
are counter-hegemonic. Atton (2004) also opens the door to an approach whereby one media form at one point in time or in one context is mainstream and in another is alternative. The difficulty in defining media as alternative or mainstream is also expressed by alternative media practitioners in a study by Harcup (2011).

The writers in the present study are not part of a group that produces alternative media together, but are rather individual writers on a for-profit citizen media website. The citizen media website is alternative in the sense that it offers an alternative to mainstream media and to some extent gathers those who are excluded from it, hence in line with the second approach described by Bailey et al. (2008) and Fuchs' (2010) definition. It to some extent also gathers controversial and radical writers, in accordance with Atton's definition (2002) and also suggested by the analysis of the writers' objectives. Alternative media are also characterized by having low barriers for people to participate in content production, something these writers' stories confirm.

Alternative media theory and the use of concepts such as power and hegemony contribute to answering the overarching research question regarding participation and restraining factors for participation and debate on the Web. This approach enables an understanding of their practices as part of the broader political, with focus on power, compared to a more narrow analysis of their practices as a form of journalism.

In the present study, citizen journalism research is nevertheless also of interest, as some informants describe their writing using a journalistic discourse, and the website on which they are active has a news web format. Some definitions of citizen journalism emphasize the independence from professional journalism - that producing a news product should be unpaid work (Nip 2006) and others include the contribution to the community (Carpenter 2010). One of the proponents of citizen media is Gillmor (2006), who describes the potential of citizen journalism to empower what he calls the "former audience". In his view, the consumer can now be a citizen journalist, and he expects that some will develop into professionals: "In the end, we'll have more voices and more options" (Gillmor 2006).

\section{The Study}

The present study was carried out in a Swedish context where blogs and grass-roots, alternative and commercial citizen media websites are some examples of media that allow citizens to publish their opinions online.

The Swedish population has a great degree of access to the Internet in the home, and recent reports state that Sweden is ranked number one in several international measures of the successful use of ICT (Findahl 2011). Citizens in Sweden thus have good basic conditions for online opinion-writing and participating.

The objective of the present study is to explore and understand the experiences of writing and debating in alternative or citizen media online from the non-elite, common Swede's perspective. The overarching interest is to understand how participation is impeded or enabled. The research focus can be expressed in a few questions:

1. How do the grass-roots writers describe their objectives and what kind of new media landscape do they describe?

2. What kind of participation is expressed? 
3. What benefits and risks do the grass-roots writers speak of regarding their possibilities to write in citizen and alternative media?

The research approach has been to inductively explore, using qualitative methodology, the experiences of the grass-roots writer online. This approach is appropriate when the researcher wants to stay open to new perspectives on the topic. The method for gathering material was to interview the informants in a semi-structured way, using the same themes for all respondents, but also using different questions and follow-up questions depending on the specific interview situation, thus using some structure though remaining flexible (Ritchie and Lewis 2003:87, Gibson and Brown 2009:11). This was expected to promote keeping an open mind to what the informants considered important to speak about regarding the topic. The analysis approach was material driven. This made it possible to stay close to the participants' stories as long as possible.

Theory within the field gave the material meaning in a later phase of the study, when the themes emerged. Thus in an initial phase, the material was organized and sorted by reading and structuring it into initial themes using open-coding. Informed by the themes, theory that could aid in interpreting the material was studied, in line with an inductive approach and with a focus on the overarching questions. The research within alternative media and media participation came into the foreground, because the material pointed towards paying attention to power, resistance and participation in a broad political sphere. Theory thus helped to understand the material in a specific way (Gibson and Brown 2009: 11). The process can be described as iterative in nature, involving moving between the material and theory to construct a picture of the participants' experiences.

\section{Selection and Material}

A group of 18 informants was selected for the semi-structured interviews. Because the aim was to achieve a grass-roots perspective, it was important that the study not investigate professional writing and well-established politicians' or opinion-formers' experiences. The focus of the study led to the selection of participants from a citizen media news website. Criteria for participation were that they should:

- write on a non-profit basis for their own purposes (not for an organization) and

- write in the politics and civil society section of the news website.

The informants who agreed to participate were between 28 and 79 years of age. There were four women and 14 men, and they had published from just a few to more than 200 articles (the median was 72) on the citizen media website. They had an average of 467 readings per article. Even though the website states that there are mechanisms in place to prevent manipulation of the statistics on readers/clicks, it is difficult to validate the numbers; nevertheless, this gives an idea of their audience. This group had various degrees of experience, and stated that they were independent writers when writing on this website (they were not writing on behalf of any organization).

Because these online writers were only available via e-mail, if at all, it was impossible to know beforehand who one was contacting. There was, at the most, a brief profile presenting them on the website. The participants were dispersed across the country and none of them lived in the immediate region; thus the interviews were carried out over the 
telephone or online via Skype. This could also be more convenient for the interviewee (Gibson and Brown 2009: 94).

Prior to the interviews, the informants received an information leaflet allowing them to give informed consent. The leaflet stated that participation was voluntary and that their identity would be kept confidential.

The interview guide had three themes, which were expected to bring out the writers' views and experiences on the research topic: Writing objectives and practices, Discussions and article commenting online, and New media and use of technology. The participants discussed their experiences both on the citizen media site where they were found as well as on other platforms where they wrote and discussed matters as independent citizens. The material consisted of 150 pages of transcribed interviews.

\section{The Citizen Journalism Website}

Because the research questions concern citizen journalists or grass-roots opinion writers in alternative or citizen media online, it was important to select informants with various experience of the online public debate. This selection was expected to give rise to a multitude of stories of navigating the new media landscape to contribute to or impact the public debate. Thus, focusing on a news website for citizen journalists was a purposeful choice.

The website can be described as a for-profit alternative medium, in the sense that it is owned by a corporation, publishes anyone's articles (low barriers to entry), and is considered an alternative to mainstream media. It has a legally responsible publisher, publishing policies to follow Swedish law and reviews before publishing. It also has additional rules to prohibit slander and organized opinion and commercial campaigns.

It has the format of a common news website with the divisions Politics and Society, Sports, Business, etc., and also features comments. An overview of the content of the politics and society section before selection indicated that a majority of the articles contained texts with personal opinions.

During the interviews, the writers mentioned writing topics such as critique of the EU, drug industry, health food industry, capitalism, energy politics and welfare politics. but also education, the Israeli-Palestinian conflict, environmental issues, spirituality, anti-globalization and democracy.

\section{Results}

\section{The Meaning of Writing}

One topic that was in focus in designing the study was the participants' purposes in writing and debating. What is their aim, and what do they want to achieve by writing and participating in a public debate?

Broadly, their purposes could be divided into two types of interest, one concerning authorship and the writing practice as a main driving force. The pleasure of writing was mainly what brought them to the citizen media website. The other direction, concerning debating, reflects a desire to be part of a public debate. Indeed this is a simplification, and the three informants who emphasized authorship as important nevertheless described their writing as argumentative, for instance aiming to "make people start thinking". The 
few authors were, like many of the others, engaged in writing about social inequalities and had an alternative perspective, which is typical of alternative media. The debaters, the group to which the majority of the informants belonged, emphasized wanting to spread their opinion and impact the debate.

The informants' objectives for participation in the public debate were expressed in terms of a variety of ambitions, from just "getting something out of my system" to "changing the world". Many of the purposes mentioned are in line with what alternative media producers stated as their motivations in a study by Harcup (2005): rage, contributing to the political and dissatisfaction with the mainstream media. The writers in Harcup's study were, however, both professional journalists and writers in the alternative media.

One major objective for the writers was to start a debate, have influence and spread their view, and an opinion was also expressed that the mainstream media did not cover the topics they wanted to be covered or that needed to be written about, as well as that the mainstream media only let a limited group of people speak. They expressed a need to inform and influence people about things they were unaware of and did not discuss. Topics could be the European Union, Swedish health care authorities, foreign policy or social change.

Exposing unfairness is also mentioned as a motive for alternative journalists in Harcup's (2011) study, although Harcup's participants were part of an alternative media organization and those in the present study can be better described as sole online writers.

Some participants described wanting to write about things the mainstream media neglected. Most writers expressed criticism towards mainstream media or journalists. This is a typical characteristic of alternative media and is discussed as a "second approach" to understanding alternative media. Bailey et al. describe this approach as being "a supplement to mainstream media, or as a counter-hegemonic critique of the mainstream" (2008: 15). Some informants position themselves as an alternative to mainstream media, challenging what they describe as topics that are never written about or perspectives that are always left out. With their texts on topics such as globalization, spirituality, alternative medicine, the European Union and alternative theories on the 9/11 attack, they try to challenge meaning-making within these areas, similar to what some of Harcup's (2011) practitioners expressed.

One informant expresses why he started writing in the following way:

I want to express myself in some way. I have opinions you know and feel like many opinions I have don't come out in the media. I want to bring them up in the media and I partly want to express my view and I think it's almost a democratic principle that one's opinions should be heard, should be expressed, especially if they reach beyond the politically correct.

Some are very critical of the mainstream media for being politically correct and for ignoring alternative angles on news stories. It is thought to be difficult to publish in the mainstream media, even though some had managed to publish debate articles. Their stories depict the mainstream media as the mighty media, unreachable and elitist. Criticism of the mainstream media was expressed in several ways: for being the media of experts and elite, for treating writers with alternative views in a stigmatizing or stereotyping way, for being lazy and publishing official versions that are too polished and correct. 
As Bailey et al. (2008: 17) define "Approach two: Alternative media as an alternative to mainstream media", the mainstream media naturalize the "common sense" but alternative writers contest the hegemonic meanings "through discursive practices". However, there is no guarantee that the producers working within alternative media will write in a counter-hegemonic manner (2008: 17).

The participants' driving force seems to be personal, and they do not express being part of a larger group with similar opinions or aims. One states that they are lone writers, and that they compete rather than cooperate. He laughs and says, "We don't have a trade union". They do not mention any community or group they support by writing.

In the stories there are often signs of passion and emotion, something Mouffe (2005) emphasizes as unavoidable and one of the strongest forces in the political. With this view, it is not surprising that the participants describe their writing as something that is brought about by emotions and affects.

Thus many of them can be interpreted as counter-hegemonic in their practices and opinions about the dominant media or dominant politics. First, many describe themselves and their writing and opinions as controversial or as bringing up new perspectives. Some also describe counter-hegemonic practices such as starting anti-capitalist campaigns in social media, creating an alternative media website, contacting journalists to critically investigate their stories, etc. Second, the counter-hegemony is expressed in opinions regarding the mainstream media, which are considered to suppress things, be unable to cope with unusual topics and described as reproducing the natural: "When it is hard to categorize in left/right then things get blurred for the journalists", "I believe some facts are censored by those large media, such as alternative explanations [about the conflict in Libya]". Finally, a few also experienced exclusion or otherness. Some have been called names or antagonized in the mainstream media: "I was called a nutcase on [a print media] editorial page". Some are also being positioned by other grass-roots writers as strange, in comments on their texts: "What planet do you come from?" or "I feel sorry for your family". This counter-hegemony is an example of resisting power, and as Carpentier (2011a) states, it is a form of resistance to turn to alternative media even though they meet restricting powers there too, as will be discussed in the section on benefits and perils.

\section{What Kind of Participation do they Describe?}

This part answers the research question regarding the kind of participation that is expressed. By first distinguishing their practices and ideas from access and interaction, it is possible to understand whether this is to be regarded as participation that has a power dimension. Second, by using the distinction between participation in and through media, developed by Carpentier (2011a, 2007), it is possible to shed more light on the form of participation and on whether it regards participation in media production or also participation in society through media production (Carpentier 2011a: 70).

Carpentier (2011b:31) emphasizes that participation is a political process and hence more than mere access to or interaction with media, and that it should include equalized power relations in decision-making or influence. One approach to analysing their practices and ideas about writing, as being participatory or not, is to pay specific attention to the power dimensions implicit in their stories. In the citizen journalist website, these 
writers determine the topics themselves, and have the opportunity to publish, hence to participate in media production. The content is written from their personal perspective and is in practice always published. Most participants express the will to impact a debate, even though authorship was the main driving force for a few. The opportunity to decide what to write and publish and the power to use their voice in the public emphasize a power dimension within the alternative and new media landscape. This distinguishes their practices and ideas from mere access and interaction, which do not imply power to influence or decide but, nevertheless, form the preconditions for participation.

Participation is further understood by discussing their practices and ideas as participation in or through media and also by discussing their objectives as reaching either the narrow politics or the broader political. The broader political would be one indicator of a maximalist form of media participation (Carpentier 2011a: 69).

Their practices are examples of participation in the media because, as discussed above, they produce media content and have full decision-making power over choice of topic (content-related participation) (Bailey et al. 2008: 11). They also participate through the media in that all writers reported having been part of discussions and public debate, and some had seen their contributions spread to other websites. A few of the writers had also been invited or contacted by mainstream TV stations after writing online. This indicates that the writers occasionally influence the mainstream media and the major TV debate shows.

Furthermore the writers themselves describe their objectives and ideas by emphasizing participation through the media, as most seem to see themselves as contributors to a public debate, thus participation in society through the media is the main objective. Participation in the citizen media website is not mentioned as a primary aim, neither in terms of contributing content or being able to co-decide in managing the website. Rather, for most of them, the media provide a means to reach the public. They mostly describe what they do or aim to do with phrases such as: "impact debate", "inform", "communicate", "give a sense of community", "spread arguments", "convey messages", "change", "lead to something positive", etc. This suggests that it is the impact on the public rather than co-producing in the media that is the main goal of participation, thus a matter of participation through the media.

Their descriptions of what they do also suggest aiming to reach the broad political sphere, as they describe their objectives with writing and debating as being directed to for example: "citizens", "people", "the society", "the debate", "the media", "Swedes", "everyone", etc. This suggests that debating in the new media landscape mainly targets the general public, not politics or its institutions. The aim of reaching a broad political sphere and the combination of in and through participation suggest that they practice a maximalist (Carpentier 2011a: 69) form of participation through the media.

I have a message that I want to give to people and I do that anywhere I can basically.

If one expresses something and participates in the debate, then one is not totally powerless, you may feel you could have an influence. Though maybe it's an illusion but one maybe feels one has ... in a way you react to what's happening in the world and in Sweden. 


\section{The Benefits and Perils of Writing and Debating}

This section of the article answers the research question that concerns the positive and negative experiences of being a citizen writer online.

Although, as we will see, there are many difficulties associated with participating, the writers are positive about having the opportunity to reach an audience. Most of them had tried writing letters to editors and as well debate articles, and express disappointment at the lack of feedback; either your text is rejected or accepted, but it does not lead to any visible discussion. One reason for their optimism about debating online is probably their negative experiences of writing to print mainstream media.

The participants in the present study describe that some of their former fellow writers on the citizen media website had moved on to other media as professionals. Among the informants, there were different ambitions to evolve as a writer. Gillmor (2006) predicted that some citizen writers would become professionals, which this study can confirm. One writer said that today, after years of writing on the citizen media website, she now sees herself more as a public person. She states that if you want to succeed as a debater, you must concentrate on a topic about which you have a passion and interest. Another writer had become a paid opinion column writer, but she was also still active on the citizen media website. No one stated that they had turned professional altogether, but some had hopes for a future professional writing career of some kind. This concurs to some extent with Harcup's (2011) study, in which all alternative journalists in time had moved on to the mainstream media. However, only some participants in the present study express this as an aim. One writer stated that the citizen media website was her "writing gym", and one stated that he tested his new arguments in the comments section. Another said that the great thing about this citizen media website is that when you publish you can be sure that no error will pass unnoticed, so one has to be a really sharp writer. This is in line with what is discussed by Carpentier (2007): that participation at the micro-level equipped them for macro-level participation as debaters.

However, it was not only the aim to write professionally and for-profit that was the reason for moving on to new channels. Most informants do not express wanting to write professionally, but rather aim at creating debate, informing people and spreading their opinions, thus at participation through the media. They had ambitions to use both social media and mainstream media if they could. Several have or have had blogs on which they could decide everything themselves and publish everything they wrote, but many expressed that they did not have the time to manage the blog and that it took too much effort to get a good number of readers. Hence, similar to what Dahlgren (2011) mentions about blogs, they are often abandoned. For the writers who have a blog, the citizen media website still reaches more readers. This is also discussed by Dahlgren (2011) as a problem with what first looks like a "sprawling blogosphere" but in fact contains few political bloggers who reach an audience and a small group of mainstream bloggers who have a symbiotic relationship with the elite (Dahlgren 2011: 103).

Many seem to work strategically with a mix of platforms and alternate between them. One informant describes how he started a local activism event through social media and that local TV found it there and interviewed him about it.

So far this section has explored some expressed benefits, potential and optimism regarding the topic. However, there were many drawbacks as well. The negative experiences of participating in the public debate were mostly associated with three major 
themes: mainstream media, commentators and organized debaters. Some informants thus fear we will see a more narrow public debate in the future, in which those with controversial or more visionary ideas will be excluded. A sense of surveillance is also expressed in regard to these major forces.

Some of the writers had experiences of being contacted by the mainstream news media and television debate shows, and the risk of not being portrayed fairly was considered. One citizen writer describes being invited to a debate under false pretences, and ending up feeling very inferior and disappointed. This indicates that the alternative writers can be used in a negative way in the mainstream media, which does not help their effort to offer an alternative interpretation of a topic. Another turned the offer down:

I was invited to a show like this, a debate once, and then I was supposed to be for or against a certain topic and then I said 'Well I can see both aspects, I see both sides' but then it wasn't interesting to have me because they almost want to incite people against each other.

The up side of this, however, is that their writing does reach the large media corporations.

Some of the participants describe their writing as controversial or as opposing societal phenomena, and they say that the mainstream media have no room for this. This is thought to provoke the mainstream media, and two of the informants report having been verbally attacked by them and by associations that oppose alternative explanations of events such as the terrorist attacks of $9 / 11$ or topics like alternative medicine or spirituality. One of these writers is interested in many topics, such as health care, politics, globalization, alternative medicine and spirituality, and expresses a feeling of forceful and organized countering in the debates and comment sections. He is sure there are associations that do this in a more or less organized manner. These associations are perceived as strategically commenting on and opposing writers online.

There are quite unpleasant areas about this, there are various organizations in society that more or less in different ways want to keep it clean, to be hygienic, that you can't think the way you want.

Some express fears that it will be harder to publish online in the future and that there is an atmosphere in which worldviews and interpretations that are simply different will be suppressed. Furthermore, some informants strongly fear that the current debate on "cleaning up" the Internet forums by restricting or shutting down commenting will narrow the overall scope of discussion, and one expresses that we risk "throwing the baby out with the bathwater" in the process.

Tough and uncivil debates between commentators were also a problem that impeded participation. Risks of being harassed in debates were handled in different ways. One never read the comments, another responded once or twice, and a third tried to address possible responses beforehand. Some handled it by ignoring uncivil comments but responding to those that seemed genuine. These negative experiences of commenting sections seemed to make the participants think twice about debating and writing. When restrictive powers (Carpentier 2011a: 147) of other grass-roots writers or organized debaters impede participation through "bad" debating, even within the alternative media to which many have turned when disappointed with the mainstream media, some informants are concerned about what this will mean in the long run. 
Some writers had also thought about the fact that future employers could find their texts and debates on the Web, and saw this as something that held them back. One had shut down a blog after her employer had mentioned that it was disloyal, and another had started publishing some texts anonymously.

I've become more restrictive sometimes actually. Especially when I just got a job or when I've had jobs in different places, then I've written less. Yes, I'm afraid it will affect me or my situation.

Employers essentially gag their employees, which means they can't speak on this matter using their own names because there's the loyalty requirement and other things.

\section{Conclusions}

The purpose of the present article was to explore the experiences of grass-roots writers online: their objectives, participation and its benefits and risks. The study adds to the previous research by presenting a problematized image of the potential of citizen participation in online debate, and it sheds light on the hopes and despair of grass-roots writers. One initial conclusion is that the writers, as the "political underdogs" that Papacharissi (2002) discussed, use the Internet to participate in the debates, where their motives range from just letting off steam to changing the world. Dissatisfaction with the mainstream media was apparent and many express counter-hegemonic ideas and practices opposing the dominant ideas of media and politics. A second conclusion is that they participate through the media and their discussions are aimed to impact the broad political rather than political institutions, hence what is important is influencing citizens and society. The third conclusion is that their practices also enable them to grow as a participating citizen. The citizen media website could be said to serve as an arena for practicing participation, and eventually some may move on to other higher-status media. The optimism regarding the Web as a space for common citizens' discussions is obvious in their stories, and many writers use a mix of alternative and social media to reach an audience. However, the online media landscape can also be understood as an arena of struggle. One final conclusion is that the alternative media online, to which many turn to be published, also have their restricting aspects. Various problems are mentioned: the commentators, organized debaters, fear of decreasing openness to alternative perspectives, fear of employers checking up on them and the mainstream media's use of alternative writers as spectacles. Some of these problems can be seen as a form of surveillance that disciplines them and impedes them from using their voice. This is in conflict with their aim for increased visibility, which is a key parameter of participation (Dahlgren 2011). Thus, if the worst comes to the worst, the restricting powers within the alternative media landscape online may keep them from using any power at all in order to participate. This is said to potentially lead to fewer alternative views and a narrower debate, contrary to a vision of more voices. 


\section{References}

Atton, C. (2002) Alternative media, London: SAGE.

Atton, C. (2004) An alternative internet, Edinburgh: Edinburgh University Press.

Bailey, O.G., Cammaerts, B. and Carpentier, N. (2008) Understanding alternative media, Issues in cultural and media studies, 99-2996897-0, Maidenhead: McGraw Hill/Open University Press.

Carpenter, S. (2010) 'A study of content diversity in online citizen journalism and online newspaper articles', New Media \& Society, 12(7), 1064-1084.

Carpentier, N. (2007) 'Section Two: Introduction Participation and Media' in Cammaerts, B. and Carpentier, N., eds., Reclaiming the media : communication rights and democratic media roles, Bristol, UK: Intellect Books.

Carpentier, N. (2011a) Media and participation: a site of ideological-democratic Struggle, Bristol: Intellect.

Carpentier, N. (2011b) 'The concept of participation. If they have access and interact, do they really participate?', Communication management quarterly, 6(21), 13-36.

Coyer, K., Dowmunt, T. and Fountain, A. (2007) The alternative media handbook, London: Routledge.

Dahlgren, P. (2005) 'The Internet, public spheres, and political communication: Dispersion and deliberation', Political Communication, 22(2), 147-162.

Dahlgren, P. (2011) 'Parameters of online participation: Conceptualising civic contingencies', Communication management quarterly, 6(21), 87-110.

Dahlgren, P. and Carpentier, N. (2011) 'Introduction: Interrogating audiences - Theoretical horizons of participation', Communication management quarterly, 6(21), 7-12.

Downey, J. and Fenton, N. (2003) 'New media, counter publicity and the public sphere', New Media \& Society, 5(2), 185-202.

Fenton, N. (2008) 'Mediating hope', International Journal of Cultural Studies, 11(2), 230-248.

Findahl, O. (2011) 'Swedes and the Internet 2011', 2012available: http://www.iis.se/docs/SOI2011-en.pdf [accessed 10 January 2012].

Fuchs, C. (2010) 'Alternative Media as Critical Media', European Journal of Social Theory, 13(2), 173-192.

Gibson, W. J. and Brown, A. (2009) Working with qualitative data [Electronic resource], Los Angeles: SAGE.

Gillmor, D. (2004) We the Media: Grassroots Journalism by the People, for the People, Sebastopol, CA: O'Reilly.

Harcup, T. (2005) '“I'm Doing this to Change the World": journalism in alternative and mainstream media', Journalism Studies, 6(3), 361-374.

Harcup, T. (2011) ‘Alternative journalism as active citizenship', Journalism, 12(1), 15-31.

Himelboim, I. (2011) 'Civil Society and Online Political Discourse: The Network Structure of Unrestricted Discussions', Communication Research, 38(5), 634-659.

Karlsson, M. (2011) 'Flourishing but restrained: The evolution of participatory journalism in Swedish online news, 2005-2009', Journalism Practice, 5(1), 68 - 84.

Laclau, E. and Mouffe, C. (2001) Hegemony and socialist strategy : towards a radical democratic politics, London: Verso.

Lee, J.K. (2007) 'The Effect of the Internet on Homogeneity of the Media Agenda: A Test of the Fragmentation Thesis', Journalism \& Mass Communication Quarterly, 84(4), 745-760.

Mitchelstein, E. and Boczkowski, P. J. (2009) 'Between tradition and change', Journalism, 10(5), 562-586.

Mouffe, C. (2005) On the political, Thinking in action, London: Routledge.

Nip, J.Y.M. (2006) 'Exploring the Second Phase of Public Journalism', Journalism Studies, 7(2), 212-236.

Papacharissi, Z. (2002) 'The virtual sphere: The internet as a public sphere', New Media \& Society, 4(1), 9-27.

Pateman, C. (1970) Participation and democratic theory, Cambridge studies in sociology (Cambridge U.P.), 0068-6808, London: Cambridge University Press.

Ritchie, J. and Lewis, J. (2003) Qualitative research practice : a guide for social science students and researchers, London: SAGE.

Thurman, N. (2008) 'Forums for citizen journalists? Adoption of user generated content initiatives by online news media', New Media \& Society, 10(1), 139-157.

Winsvold, M. (2009) 'Arguing into the digital void? On the position of online debates in the local public spheres of four Norwegian municipalities', Javnost-the Public, 16(3), 39-54.

Winther Jørgensen, M. and Phillips, L. (2002) Discourse analysis as theory and method, London: Sage.

Wojcieszak, M.E. and Mutz, D.C. (2009) 'Online Groups and Political Discourse: Do Online Discussion Spaces Facilitate Exposure to Political Disagreement?', Journal of Communication, 59(1), 40-56.

SOFIA LARSSON, Ph.D. Student, Department of Arts, Communication and Education, Luleå University of Technology, sofia.1.larsson@1tu.se 